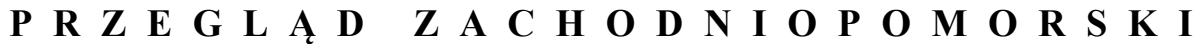 ROCZNIK XXXIII (LXII) ROK 2018 ZESZYT 3
}

\section{HENRYK WALCZAK \\ Uniwersytet Szczeciński, Wydział Humanistyczny \\ e-mail: Henryk_Walczak@poczta.fm \\ Józef Pilsudski wobec sojuszu Polski z Rumunia W OKRESIE MIĘDZYWOJENNYM}

Słowa kluczowe: Józef Piłsudski, Rumunia, okres międzywojenny, stosunki dyplomatyczno-wojskowe

Keywords: Józef Piłsudski, Romania, the inter-war period, diplomatic and military relations

Katastrofa militarna oraz wstrząsy społeczne i narodowościowe, będące udziałem Rosji, Austro-Węgier i Niemiec, sprzyjały urzeczywistnieniu niepodległościowych dążeń Polaków. Okoliczności te wpłynęły również znacząco na realizację dążeń zjednoczeniowych Rumunii, która po wojnie bardzo rozszerzyła swoje terytorium. Granice Rzeczypospolitej, tak jak i Królestwa Rumunii, wykuwane były w sporach politycznych i dyplomatycznych, a także w wyniku regularnej walki zbrojnej. Polacy wyznaczali swoje granice w starciach z Niemcami, Rosją Sowiecką, Litwą, Ukraińską Republiką Ludową (URL), Zachodnioukraińską Republiką Ludową (ZURL) oraz Czechosłowacją. Włączenie w skład Rumunii Besarabii, Siedmiogrodu i Dobrudży stawiało ją w obliczu wrogości Rosji Sowieckiej, Węgier i Bułgarii ${ }^{1}$.

${ }^{1}$ J. Pajewski, Budowa Drugiej Rzeczypospolitej 1918-1926, Kraków 1995, s. 36 i n.; M. Willaume, Rumunia, Warszawa 2004, s. 86 i n.; o meandrach polityki Rumunii w czasie I wojny światowej zob. także, Wielka Wojna, Rumunia, królowa Maria (1916-1919), w: Polska i Rumunia $w$ Europie Środkowej w XX $i$ XXI wieku. Studia, materiaty i eseje poświęcone pamięci prof. dra hab. Wojciecha Rojka. Polonia și România în Europa Centrală în secolele XX și XXI. Studii, 
Początkowo Rumunia budziła zainteresowanie Naczelnika Państwa Józefa Piłsudskiego w kontekście walk z ZURL, które wybuchły na początku listopada 1918 roku. Zapewne w początkach grudnia wyruszył do Bukaresztu Tadeusz Gwiazdoski ${ }^{2}$, mianowany sekretarzem tamtejszego poselstwa, z kopią depeszy Piłsudskiego, który jako Naczelnik Państwa notyfikował 16 listopada mocarstwom zwycięskiej koalicji powstanie niepodległego państwa polskiego ${ }^{3}$. W lutym 1919 roku Piłsudski w wywiadzie dla korespondenta dziennika włoskiego „Il Secolo” wskazał na potrzebę posiadania wspólnej granicy z Rumunią, pożądanej ze względu na połączenie RP z wybrzeżem Morza Czarnego i istotnej „bardzo z punktu widzenia ekonomicznego"4. Polskie inicjatywy w sprawie nawiązania współpracy nie wywoływały jednak większego rezonansu w Bukareszcie. Istnienie ZURL było bowiem dla Rumunów dogodnym buforem, oddzielającym ich kraj od Rosji Sowieckiej, szerzącej wywrotowe idee i domagającej się zwrotu Besarabii. Skuteczne działania wojsk polskich przeciwko Ukraińcom w Galicji Wschodniej wiosną 1919 roku sprawiły, że w Bukareszcie zaczęto brać pod uwagę możliwość przejęcia przez RP roli ukraińskiego bufora. Aby nie zamykać sobie możliwości współpracy, Rumuni zdecydowali się 24 maja 1919 roku wysłać na Pokucie swoje oddziały, mające występować jako sojusznicy armii polskiej5.

materiale și eseuri dedicate in memoriam prof. dr univ. Wojciech Rojek, red. A. Kastory, H. Walczak, Kraków 2017, s. 307-315.

${ }^{2} \mathrm{O}$ działalności Gwiazdoskiego w Bukareszcie zob. H. Walczak, Polscy przedstawiciele dyplomatyczni w Rumunii w latach 1918-1940, cz. 1: 1918-1940, „Polish Biographical Studies” 2016, nr 4, s. 28-33.

${ }^{3}$ Pismo M. Lindego z 11.12.1918 r. (nr 13) do rumuńskiego ministra spraw zagranicznych, Arhivele Ministerului Afacerilor Externe. Bucureşti (dalej: AMAE) 71 /1914, E2, partea I, vol. 4, k. 19; D. Hrenciuc, România şi Polonia - 1918-1931. Relaţii politice, diplomatice şi militare, Rădăuţi 2003, s. 30; H. Bułhak, Polska a Rumunia 1918-1939, w: Przyjaźnie i antagonizmy. Stosunki Polski z państwami sąsiednimi w latach 1918-1939, red. J. Żarnowski, Warszawa 1977, s. 305; F. Anghel, Wspólna pamięć Intermarium. Określenie przebiegu granic i nawiazanie stosunków dyplomatycznych między Rumunia a Polska po I wojnie światowej: România Mare oraz Polonia Restituta, w: Międzymorze. Nadzieje i ograniczenia w polityce II Rzeczypospolitej, red. E. Znamierowska-Rakk, Warszawa 2016, s. 307.

${ }^{4}$ J. Piłsudski, Pisma zbiorowe, t. 10, Warszawa 1938, s. 178.

${ }^{5}$ F. Anghel, Okupacja Pokucia przez Armię Rumuńska (24 maja-początek sierpnia 1919 r.) i początki stosunków polsko-rumuńskich, „Przegląd Historyczny” 1998, z. 2, s. 256; W. Stępniak, Dyplomacja polska na Batkanach (1918-1926), Warszawa 1998, s. 54-55; V. Kroytor, Problema Pokuttiya u vidnostinakh mizh Rumunieyiu i ZUNR, „Galitschina” 2001, nr 5-6, s. 233; M.C., Stănescu, Operaţia Pocuţia, mai-august 1919, „Magazin Istoric” 1995, nr 1, s. 10-12; H. Walczak, Sojusz z Rumunia w środkowoeuropejskiej i batkańskiej polityce Polski w pierwszej połowie lat dwudziestych XX wieku, w: Międzymorze..., s. 314-315. 
Zetknięcie się obu armii stanowiło osiągnięcie jednego z zasadniczych celów ofensywy przeciwko Ukraińcom, podjętej z rozkazu Piłsudskiego. W jego opinii osiągnięcie łączności z Rumunią zapowiadało, że „Polska na wypadek wojny z Niemcami nie (...) [będzie] odcięta od całego świata i pozostawiona sama przy orężnym starciu z Niemcami i wojskiem bolszewickim"•.

Dążąc do zrealizowania tej zapowiedzi, dyplomacja polska czyniła zabiegi o polityczne, wojskowe i gospodarcze zbliżenie z Rumunią. W Bukareszcie nadal odnoszono się do tych zabiegów z dystansem. Kontrola Polski nad Galicją Wschodnią oraz władza atamana Symona Petlury nad Naddnieprzem stanowiły dla Rumunii osłonę przed wpływami bolszewickimi i hamowały przed zaangażowaniem w porozumienie $\mathrm{z}$ Warszawą, mimo podejmowanych przez nią wielu prób?

Jedną z nich była misja gen. Tadeusza Rozwadowskiego w Bukareszcie, realizowana od 30 kwietnia do 10 maja 1920 roku. Piłsudski zalecał, by gen. Rozwadowski wyraźnie zaznaczył, że polityka RP nie bierze pod uwagę jakiejkolwiek okupacji terytorium URL. Miał też zaproponować Rumunom wspieranie Ukrainy petlurowskiej w organizowaniu własnej państwowości. Ukraina byłaby barierą oddzielającą Polskę i Rumunię od Rosji, a ze względu na słabość musiałaby szukać oparcia dla utrzymania swojego istnienia nad Wisłą i Dâmbovițą. URL, skierowana frontem na Wschód, byłaby wałem zabezpieczającym ludność ukraińską zamieszkującą Polskę (Galicja Wschodnia, część Wołynia) i Rumunię (Besarabia, Bukowina). Udziałem RP w formowaniu niepodległej Ukrainy byłby wysiłek militarny w wyparciu bolszewików oraz pomoc w organizacji jej armii i państwowości przez Polaków pochodzących z tych ziem. Od Rumunii Piłsudski oczekiwał poparcia polskiej polityki wobec Ukrainy, uznania rządu Petlury oraz przekazania na rzecz URL uzbrojenia skonfiskowanego oddziałom ukraińskim, które przekroczyły Dniestr i przeszły do Królestwa. Wspólna polityka Warszawy i Bukaresztu w kwestii Ukrainy pozwoliłaby obu państwom korzystać z jej bogactw, a także mogłaby doprowadzić do usamodzielnienia się względem Ententy

\footnotetext{
${ }^{6}$ Telegram J. Piłsudskiego do G. Clemenceau z 31.05.1919 r., w: Sprawy polskie na konferencji pokojowej w Paryżu w 1919 r. Dokumenty i materiaty, t. 2, red. R. Bierzanek, J. Kukułka, Warszawa 1967, s. 331.

${ }^{7}$ H. Walczak, Sojusz z Rumunia $w$ polskiej polityce zagraniczej $w$ latach 1918-1931, Szczecin 2008, s. 74-89.
} 
w kwestiach wschodnich i zneutralizowania niebezpieczeństwa grożącego obu krajom zarówno ze strony Rosji czerwonej, jak i białej

W czasie pobytu gen. Rozwadowskiego w Bukareszcie Rumuni, będąc pod wrażeniem polskich sukcesów w walkach z Armią Czerwoną, demonstrowali wolę zawarcia aliansu z RP. Jednakże zmiana sytuacji na froncie i marsz bolszewików ku Wiśle odwiodły ich od tego zamiaru. Zainteresowanie zbliżeniem z Polską powróciło w Bukareszcie po polskich zwycięstwach i podpisaniu preliminariów pokojowych w Rydze w październiku 1920 roku. Wówczas to minister spraw zagranicznych Take Ionescu wystąpił z ideą włączenia Polski i Grecji do kształtującej się Małej Ententy (Czechosłowacja, Królestwo SHS i Rumunia). Ze względu na antywęgierskie ostrze tego bloku oraz antagonizm polsko-czechosłowacki Polacy nie przejawiali entuzjazmu dla tego projektu. W związku z tym Ionescu przybył do Warszawy i od 1 do 4 listopada 1920 roku prowadził rozmowy z polskimi politykami. Doszło wtedy m.in. do spotkania z Naczelnikiem Państwa. Można sądzić, że Piłsudski nie wyrażał przychylności dla realizacji tej koncepcji. $Z$ tego też powodu polityk rumuński nie zdecydował się oficjalne wystąpić z propozycją przystąpienia RP do bloku dunajskiego. Z drugiej strony Ionescu nie przejawiał gotowości do rozmów na temat dwustronnego aliansu polsko-rumuńskiego9.

Chęć zawarcia przymierza z Polską wzrosła w Bukareszcie po zwycięstwach Armii Czerwonej nad wojskami białogwardyjskimi i petlurowskimi oraz osiągnięciu przez nią granicy z Rumunią na Dniestrze. Dyplomacja polska wykorzystała zaniepokojenie Rumunów zagrożeniem bolszewickim i po dość skomplikowanych negocjacjach doprowadziła 3 marca 1921 roku do finalizacji przymierza między obu krajami ${ }^{10}$.

Od tego momentu zintensyfikowanie wzajemnej współpracy stało się jednym z najważniejszych celów stojących przed polskimi kołami politycznymi

\footnotetext{
${ }^{8}$ List J. Piłsudskiego do gen. K. Sosnkowskiego z 29.04.1920 r., „Niepodległość” 1962, t. 7, s. 97 98; instrukcja gen. Sosnkowskiego do gen. Rozwadowskiego z 4.05.1920 r. (nr 3702), w: T. Hunczak, Ukraine and Poland in documents 1918-1922, part 2, New York-Toronto 1983, s. 57-59.

${ }^{9}$ H. Bułhak, Początki sojuszu polsko-rumuńskiego i przebieg rokowań o konwencję wojskowa w latach 1919-1921, „Dzieje Najnowsze” 1973, nr 3, s. 33-38; A. Essen, Polska a Mała Ententa: 1920-1934, Warszawa-Kraków 1992, s. 23-42; Kronika Polityczna, „Kurier Warszawski” 2.11.1920, wyd. poranne, s. 2; N. Mareș, Istorie - diplomație. Eseuri, vol. 2, Iași 2014, s. 182-183; A. Kastory, Projekt polsko-węgiersko-rumuńskiej wspótpracy jako jedna z koncepcji Międzymorza w okresie międzywojennym, w: Międzymorze..., s. 382.

${ }^{10}$ H. Walczak, Sojusz z Rumunia $w$ polskiej polityce zagranicznej $w$ latach 1918-1931..., s. $116-140$.
} 
i wojskowymi. Szczególne znaczenie miała kooperacja w sferze militarnej. Zabiegał o nią zwłaszcza Marszałek Piłsudski, który w rozmowie z posłem rumuńskim w Warszawie, Alexandru Florescu, zapowiadał wysłanie do Bukaresztu w charakterze attaché wojskowego swojego zaufanego współpracownika, ppłk. Bolesława Wieniawy-Długoszowskiego. Attaché wyruszył nad Dâmboviţę, aby doprowadzić do zacieśnienia współpracy między obu armiami oraz zniwelować niespójności między konwencją militarną a układem politycznym ${ }^{11}$.

Początkowo Rumuni nie dostrzegali konieczności konsolidacji związków sojuszniczych z Polską, bagatelizując niebezpieczeństwo płynące dla obu krajów ze strony Rosji Sowieckiej. Z zamiarem zmiany tego stanu rzeczy z wizytą do Rumunii udał się 13 września 1922 roku sam Naczelnik Państwa. Pobyt (w dniach 14-16 września) upłynął w Sinai - rezydencji królewskiej, gdzie Piłsudski spotykał się m.in. z królem Ferdynandem, królową Marią, premierem Ionem Brătianu oraz synami królewskimi - ks. Karolem i ks. Mikołajem ${ }^{12}$.

Naczelnik Państwa zrobił przy powitaniu ogromne wrażenie na królu. Książę Mikołaj zanotował wówczas: „Udaliśmy się z mym ojcem królem Ferdynandem na dworzec, aby spotkać przybywającego z oficjalną wizytą Naczelnika Państwa Polskiego, Marszałka Piłsudskiego. Miałem wrażenie, że ojciec mój ma zamiar przyjąć swego gościa serdecznie, ale z pewną nonszalancją. Pomimo wszystko Marszałek, Naczelnik Państwa to nie król. Ojciec mój rozmawiał z nami wesoło, gdy pociąg podchodził, a gdy stanął, zapalił właśnie papierosa. Z salonki wprost przed nami wyskoczyli dwaj adiutanci i świetnie stanęli na baczność po obu stronach drzwi. Po chwili ukazał się w tych drzwiach (...). Marszałek i lekko pochylony naprzód patrzał na naszą grupę. Potem wolno, bardzo wolno zaczął wychodzić. Było w tym wzroku coś takiego, że wyprostowałem się mimo woli. Spojrzałem na mego ojca i nie zapomnę nigdy, skonstatowałem, że zanim Marszałek zdążył zejść, ojciec mój rzucił papierosa i stanął na baczność’13.

Król Ferdynand nie zrobił na Piłsudskim równie wielkiego wrażenia. W jego opinii był to „dobry i poczciwy człowiek o przeciętnej inteligencji”, natomiast

${ }^{11}$ Raporty A. Florescu do T. Ionescu z 30.10.1921 r. (nr 3619) i 7.11.1921 r. (nr 3747), AMAE, 71/1920-1944, Polonia, vol. 14, k. 138-138a, 145; list ppłk. B. Wieniawy-Długoszowskiego do J. Piłsudskiego z 27.01.1922 r., Archiwum Akt Nowych w Warszawie (dalej: AAN), Akta B. Wieniawy-Długoszowskiego, t. 17, k. 1.

${ }^{12}$ H. Walczak, Wizyta Naczelnika Państwa J. Piłsudskiego w Rumunii w 1922 r., w: Józef Pitsudski (1867-1935). Polityk, wódz, mąż stanu, red. J. Faryś, T. Sikorski, Szczecin 2005, s. 83 i n.

${ }^{13}$ W. Grzybowski, Spotkania i rozmowy z Józefem Pitsudskim, „Niepodległość” (Londyn) 1948, t. 1, s. 94; zob. również: N. Mareș, Istorie - diplomație..., s. 185-186. 
„główny ton na dworze starała się narzucić królowa Maria, wykształcona, inteligentna i impulsywna, a przy tym bardzo ambitna i zabiegająca o popularność. Nie zdobyła jednak - zdaniem Naczelnika - ani popularności, ani sympatii narodu. Rumuni pragnęli widzieć w swej królowej większą dostojność, a nie tak żywy i wybuchowy temperament, jakim się odznaczała”. Piłsudski twierdził, że „najmądrzejszą, nieprzeciętnej inteligencji osobą [na dworze] była (...) księżniczka grecka Helena"'14. Z chłodnym dystansem, z czasem coraz większym, postrzegał natomiast Naczelnik Państwa jej męża, księcia Karola, następcę tronu rumuńskiego.

Mimo tych obserwacji Piłsudski starał się nadać swojej wizycie wymiar szczególnej sympatii do gospodarzy. Podkreślał „serdeczną gościnność” króla Ferdynanda i wyrażał chęć ponownych odwiedzin. W jego przekonaniu wspólnota interesów politycznych obu krajów i ,podobieństwo pewnych cech (...) charakteru” obu narodów stanowiły przesłanki do „coraz bardziej ścisłego zjednoczenia z jednej i drugiej strony wszystkich żywiołów i wszystkich sfer tak rządowych, jak i politycznych, tak kół naukowych i kulturalnych, jak sfer finansowych i ekonomicznych". Marszałek twierdził też, że sąsiedzi z reguły się spierają. Jednakże Polska i Rumunia stanowią ewenement $\mathrm{i}$ „,dobrze byłoby, gdyby inni sąsiedzi naśladowali ten przykład” ${ }^{15}$. Przy innej okazji Marszałek skonstatował, że od „Morza Bałtyckiego do Morza Czarnego jest jeden naród o dwóch sztandarach narodowych"16.

Ukoronowaniem wizyty stało się podpisanie 16 września nowej konwencji wojskowej, która zawierała zobowiązanie natychmiastowego włączenia się do wojny z Rosją Sowiecką w warunkach zaistnienia casus foederis, gdy w konwencji wcześniejszej przewidywano jedynie bezzwłoczną mobilizację. W rezultacie nastąpiło usunięcie niespójności konwencji z tekstem umowy politycznej z 1921 roku, w którym strony zobowiązywały się natychmiast przystąpić do wojny w razie zaatakowania ich granic wschodnich ${ }^{17}$.

W ślad za podpisaniem konwencji Polska wzmocniła starania na rzecz operacyjnego przygotowania współpracy armii polskiej i rumuńskiej na wypadek

\footnotetext{
${ }^{14}$ A.L. Korwin-Sokołowski, Fragmenty wspomnień 1910-1945, Warszawa 1987, s. 75-77.

${ }^{15}$ J. Piłsudski, Pisma zbiorowe, t. 5, Warszawa 1937, s. 279-280 (stąd cytat); zob. również: N. Mareș, Istorie - diplomație..., s. 186.

${ }^{16}$ J. Piłsudski, Pisma zbiorowe, t. 5..., s. 280-281 (stąd cytat); zob. również: N. Mareș, Istorie - diplomație..., s. 189.

${ }^{17}$ H. Bułhak, Materiały do dziejów sojuszu polsko-rumuńskiego w latach 1921-1931, „Studia Historyczne" 1973, z. 3, s. 422-424; M. Leczyk, Polska i sąsiedzi. Stosunki wojskowe 1921-1939, Białystok 1997, s. 60.
} 
ewentualnej wojny z Rosją Sowiecką. Było to tym bardziej wskazane, że w styczniu 1923 roku władze ZSRR zaczęły zwiększać liczbę własnych oddziałów przy granicy z RP. Pojawiły się również informacje o możliwym wystąpieniu przeciwko Polsce w razie wspomożenia przez nią Paryża w jego akcji w Zagłębiu Ruhry. Marszałek Piłsudski z jednej strony uważał, że najazd Związku Sowieckiego należy raczej wyeliminować z powodu nieprzygotowania tego państwa do wojny, z drugiej jednak strony jeszcze w styczniu 1923 roku komunikował generałowi Christescu o przygotowywanych w Polsce studiach zakładających ewentualny konflikt zbrojny z ZSRR. Wskazywał też na wagę kwestii wymiany broni między armią polską i rumuńską. Z rozkazu Piłsudskiego wyjechał do Bukaresztu ppłk Tadeusz Kasprzycki z Biura Ścisłej Rady Wojennej celem zaznajomienia Rumunów z efektami prac Sztabu Generalnego WP dotyczącymi ewentualnego współdziałania armii polskiej i rumuńskiej. Oficer ten uczestniczył także w pracach nad Studium nr 3, w którym analizowano zagadnienia kooperacji sił zbrojnych obu krajów w razie najazdu Armii Czerwonej na Rumunię ${ }^{18}$. Piłsudski pragnął kontynuacji prac studyjnych, wystąpił więc z propozycją przysłania do Warszawy wyższego oficera rumuńskiego celem wspólnego opracowania studium, którego tematem byłoby ewentualne współdziałanie wojsk polskich i rumuńskich w razie sowieckiego ataku na Polskę na północ od bagien Prypeci ${ }^{19}$.

W maju 1923 roku, przy okazji spotkania marszałka Ferdinanda Focha w Warszawie z Piłsudskim, pełniącym ówcześnie funkcję szefa Sztabu Generalnego WP, pojawiła się kwestia rozszerzenia współpracy polsko-rumuńskiej o Francję. Foch wystąpił wówczas z sugestią, aby zostać wtajemniczonym w treść konwencji polsko-rumuńskiej. Piłsudski uzależnił spełnienie jego życzenia od akceptacji Rumunów i przystąpienia Paryża do antyrosyjskiego frontu Warszawy

\footnotetext{
${ }^{18}$ Pisma marsz. Piłsudskiego do gen. Christescu z 23.01. (nr 154/IIa), 21.03. (KP) 1923 r. AMAE, 71/1920-1944, Polonia, vol. 65, k. 63, 66; pisma gen. Christescu do marsz. Piłsudskiego z 8.02. (nr 546), 4 IV (bez nr.) 1923 r., tamże, k. 64, 67; telegramy MSZ do Bukaresztu z 30.01. (nr 7), 20.02 (nr 14), 23.02. (nr 15), 26.02. (nr 16), 4.03. (nr 18) 1923 r., Hoover Institution Archives (dalej: HIA), Polska. Poselstwo (Rumunia) (dalej: Rum.), Księga szyfrów (dalej: Ks.szyf.) nr 1, pudło (dalej: p.) 1, folder (dalej: f.) 1; pismo War Office do Foreign Office z 14.02. 1923 r. (bez nr.), Documents on British Foreign Policy 1919-1939 (dalej: DBFP), Series I, vol. XXIII, s. 746-747; Studiul nr 3 privind cooperarea armatelor polono-române pentru respingerea unui atac rus împotriva României. Bucureşti 4 aprilie 1923, w: M.Ch. Popescu, Relaţiile militare româno-polone în perioada interbelică (1918-1939), Bucureşti 2001, s. 133-135 (anexa nr 33).

${ }^{19}$ Pismo płk. [Trandafirescu] do zastępcy szefa Sztabu Generalnego gen. A. Gorskiego z 27.05. 1923 r. (nr 62). Arhivele Militare Române, Bucureşti (dalej: AMR), Marele Stat Major (dalej: MSM), Biroul Ataşati Militari, t. 356, k. 137-138.
} 
i Bukaresztu. Foch skłonny był przyjąć tę propozycję, licząc na wciągnięcie Rumunii przez Polskę do rysującego się bloku i mając nadzieję - jak można sądzić - że będzie on również zwrócony przeciwko Rzeszy. Były Naczelnik Państwa ze sceptycyzmem odnosił się do możliwości porzucenia przez Francję rachub na przyjaźń z przyszłym odbudowanym państwem rosyjskim, które jego zdaniem były bardzo żywe w sferach miarodajnych III Republiki. Niemniej skłonny był zaangażować się w ustalenia z królem Ferdynandem w sprawie udostępnienia Francuzom tekstu konwencji w trakcie pobytu rumuńskiej pary królewskiej w Polsce. W rozmowach tych miał wziąć udział jako doradca króla wyższy oficer armii rumuńskiej oraz odpowiednio upełnomocniony wysoki rangą wojskowy francuski. Jeśli nie udałoby się urzeczywistnić tego projektu, Piłsudski zamierzał podjąć sprawę w czasie swojej wizyty w Paryżu, planowanej na jesień 1923 roku i doprowadzić do trójstronnych rozmów francusko-polsko-rumuńskich ${ }^{20}$.

Wyjazd Piłsudskiego do Paryża nie doszedł do skutku, ponieważ podał się on do dymisji ze stanowiska szefa Sztabu Generalnego, gdy w maju 1923 roku uformował się rząd centroprawicowy z udziałem endecji, moralnie odpowiedzialnej za zabójstwo prezydenta Gabriela Narutowicza. Marszałek, będąc jeszcze przewodniczącym Ścisłej Rady Wojennej (ŚRW), uczestniczył jednak w podejmowaniu przybyłych 24 czerwca do Polski króla Ferdynanda, jego żony Marii oraz premiera Brătianu i ministra spraw zagranicznych Iona Duki. Relacje pary królewskiej z Piłsudskim były bardzo przyjacielskie. Prawdopodobnie wspominano pobyt byłego Naczelnika Państwa w Sinai. Piłsudski wskazywał być może na konieczność dalszego prowadzenia polsko-rumuńskich studiów operacyjnych, wyjazdów oficerów obu armii na staże do kraju sojusznika czy uczestnictwa przedstawicieli sił zbrojnych obu państw w manewrach wojskowych armii sprzymierzonej. Zapewne wymieniał też uwagi w sprawie konieczności doprowadzenia do skutku negocjacji polsko-rumuńsko-francuskich oraz zagwarantowania Polsce i Rumunii swobody tranzytu przez Czechosłowację. 25 czerwca Marszałek odznaczył króla orderem Virtuti Militari I klasy, następnego dnia zaś śledził działania oddziałów polskich na poligonie w Rembertowie ${ }^{21}$.

${ }^{20}$ Raport Florescu do Duki z 8.05. 1923 r. (nr 2359), AMAE, 71/1920-1944, Polonia, vol. 52, k. 56-57; raport Florescu do Duki z 17.05. 1923 r. (nr 2532), w: România-Polonia. Relaţii diplomatice, col. de red. F. Anghel, N. Mareş, D. Preda, Bucureşti 2003, s. 26-29.

${ }^{21}$ H. Walczak, Wizyta rumuńskiej pary królewskiej w Polsce w czerwcu 1923 r., w: Post hominum memoriam. Profesorowi Januszowi Farysiowi - uczniowie i przyjaciele, red. E. Skorupska-Raczyńska, P. Słowiński, Gorzów Wlkp. 2009, s. 126-131; por. N. Mareș, Istorie - diplomație..., s. 194-203. 
Po rezygnacji z funkcji przewodniczącego ŚRW Piłsudski usunął się życia politycznego i osiadł w podwarszawskim Sulejówku, gdzie posiadał niewielki dworek $^{22}$. W tym czasie nastąpił regres w stosunkach polsko-rumuńskich, który trwał do objęcia stanowiska ministra spraw zagranicznych przez Aleksandra Skrzyńskiego w lipcu 1924 roku. Marazm w relacjach politycznych nie szedł w parze z kontaktami wojskowymi. Wyrazem postępów w tym zakresie było zwołanie do Warszawy w kwietniu 1924 roku międzysztabowej konferencji polsko-rumuńsko-francuskiej, jawiącej się jako wstęp do zawarcia trójstronnego przymierza asekurującego sygnatariuszy przed zagrożeniem ze strony Związku Sowieckiego i Niemiec. Planów tych nie udało się zrealizować ze względu na dojście do władzy we Francji rządu Eduarda Herriota, przejawiającego inklinacje do porozumienia z Berlinem i Moskwą. Dojście do skutku układów lokarneńskich w październiku 1925 roku, których konsekwencją było skierowanie rewizjonizmu niemieckiego w stronę Polski i Czechosłowacji, sprawiło, że Skrzyński, chcąc wzmocnić stanowisko RP wobec Rzeszy, skłonny był przyjąć sowiecką propozycję rokowań o pakt nieagresji i gotów był usunąć antysowieckie akcenty z polsko-rumuńskiego traktatu gwarancyjnego. Traktat ten, podpisany w marcu 1926 roku, zmodyfikował dotychczasowy model aliansu, wywołując nieufność w Bukareszcie. $Z$ drugiej strony warto zaznaczyć, że tzw. porozumienia techniczne, będące odpowiednikiem konwencji wojskowej, nie zmniejszyły zakresu wzajemnych gwarancji chroniących oba kraje przed niebezpieczeństwem sowieckim ${ }^{23}$.

Niedługo po zamachu majowym Piłsudski przedstawił kierownictwu resortu spraw zagranicznych zasady polskiej polityki zagranicznej. Oprócz ścisłej neutralności w stosunkach z Niemcami i ZSRR oraz niewchodzenia z żadnym $\mathrm{z}$ tych państw w porozumienie przeciw drugiemu na plan pierwszy Marszałek wysunął trzymanie się w dalszym ciągu linii przymierzy z Francją i Rumunią. Szczególnie mocno podkreślał wspólnotę interesów z Rumunią podczas spotkania z posłem tego kraju, Alexandru Iacovakym, które odbyło się 17 czerwca 1926 roku w Warszawie, zaznaczając brak harmonii w polityce wielkich mocarstw oraz wagę przymierza dla obrony tych interesów ${ }^{24}$.

${ }^{22}$ W. Jędrzejewicz, J. Cisek, Kalendarium życia Józefa Pitsudskiego 1867-1935, t. 2: 19181926, Wrocław-Kraków 1994, s. 334-339.

${ }^{23}$ H. Walczak, Sojusz z Rumunia w polskiej zagraniczej w latach 1918-1931..., s. 209 i n.

${ }^{24}$ Wyciąg z raportu Iacovakyego do MSZ z 17.06. 1926 r. (nr 2428), AMAE, 71/1920 -1944, Polonia, vol. 62, k. 47a-48; P. Wandycz, Z Pitsudskim i Sikorskim. August Zaleski-minister spraw zagranicznych w latach 1926-1932, 1939-1941, Warszawa 1999, s. 50-52. 
W dążeniu do zneutralizowania pogorszenia położenia międzynarodowego Polski spowodowanego podpisaniem w kwietniu 1926 roku niemiecko-sowieckiego układu o przyjaźni Marszałek zaczął nalegać na możliwie szybką ratyfikację polsko-rumuńskiego traktatu gwarancyjnego oraz demonstrował ugodowe nastawienie wobec nierozwiązanego przez Rumunów problemu odszkodowań za wywłaszczone przez nich majątki obywateli polskich w Besarabii. Bukareszt zaczął wówczas ujawniać inklinacje do bliższej współpracy z Polską, zwłaszcza że był zaniepokojony możliwością podjęcia przez Warszawę rokowań z ZSRR dotyczących paktu o nieagresji, co siłą rzeczy musiałoby doprowadzić do pogorszenia położenia Rumunii względem ZSRR. Pojawiła się wtedy inicjatywa przyjazdu do Polski premiera Averescu. Marszałek przyjął ją z ukontentowaniem. Mimo że ostatecznie nie udało się jej sfinalizować, Piłsudski w dalszym ciągu podkreślał znaczenie aliansu z Rumunią, mając nadzieję, że oba kraje będą realizowały wspólną linię wobec ZSRR. Aby przekonać Rumunów do tych działań, przekazał im w formie aide-mémoire odpowiedź Polski na sowiecką propozycję paktu o nieagresji z 24 sierpnia $^{25}$.

Okazją do zdefiniowania bieżącej polityki obu sojuszników wobec wschodniego sąsiada stały się pogłoski, jakoby Wielka Brytania, której relacje z ZSRR były w końcu 1926 roku w stanie ostrego kryzysu, organizowała przeciwko temu państwu zbrojną ekspedycję. W lutym 1927 roku doszło do spotkania Piłsudskiego i ministra spraw zagranicznych RP Augusta Zaleskiego z posłem Iacovakym, w trakcie którego szef polskiej dyplomacji zaznaczył, że Polacy i Rumuni nie znajdą się w roli „najemników Anglii”, czym zyskał aprobatę swego interlokutora. Z kolei Piłsudski, uznając konieczność pogłębienia sojuszu polsko-rumuńskiego, konstatował, że oba państwa będą się trzymać na uboczu od wojny z Moskwą. Nie wykluczał co prawda agresji ze strony Rosji, ale nie sądził, by nastąpiło to w najbliższej perspektywie. Rumuni nie byli jednak pewni, czy Warszawa nie chce ich „wciągnąć” w konflikt z ZSRR. Iacovaky w raporcie do centrali podkreślał zbieżność interesów obu państw w asekuracji przed inwazją sowiecką, ale wskazywał też na niedawną obecność w myśli politycznej Piłsudskiego postulatu przywrócenia Rzeczypospolitej przedrozbiorowej i zastanawiał się, czy mając go na względzie, Marszałek nie ulegnie podszeptom Anglii. Ewentualne

${ }^{25}$ H. Walczak, Sojusz z Rumuniq w polskiej polityce zagranicznej po zamachu majowym (do upadku gabinetu Alexandru Averescu w czerwcu 1927 r.), w: Między Europa naszych pragnień a Europa naszych możliwości, red. J. Faryś, T. Sikorski, P. Słowiński, t. 2, Gorzów Wlkp. 2007, s. $244-248$. 
zaangażowanie RP po stronie Londynu poseł uważał za sprzeczne z interesami zarówno Rumunii, jak i Francji, stojących na straży nienaruszalności powojennego porządku, obwarowanego traktatami pokojowymi ${ }^{26}$.

Tymczasem Polska, mając w perspektywie wznowienie wiosną 1927 roku pertraktacji z ZSRR dotyczących paktu o nieagresji, przestała naciskać na zintensyfikowanie relacji sojuszniczych. Na życzenie Marszałka doszło nawet do przesunięcia z lipca na listopad polsko-rumuńskiej konferencji międzysztabowej mającej się odbyć w Bukareszcie ${ }^{27}$. Zdaniem Iacovakyego Piłsudski uczynił tak, ponieważ nie chciał, w sytuacji zerwania przez Wielką Brytanię stosunków dyplomatycznych z ZSRR (27 maja 1927 r.), być obarczany przez Moskwę zarzutami przygotowywania z Rumunami planów wymierzonych przeciwko nieje ${ }^{28}$.

Niepokój Rumunii odnośnie do dalszego biegu stosunków polsko-sowieckich wywołało zastrzelenie przez rosyjskiego białego emigranta 7 czerwca 1927 roku w Warszawie posła sowieckiego Piotra Wojkowa. Piłsudski, indagowany 25 czerwca w tej sprawie przez Iacovakyego, poinformował go, że wzmożenie napięcia między ZSRR a Warszawą okazało się przejściowe i obecnie wykazuje tendencje do obniżenia. Marszałek zauważył jednak, że antysowiecka polityka Londynu może wzbudzić w przywódcach kremlowskich chęć do rozniecenia konfliktu zbrojnego, którego skutki byłby odczuwalne także dla Polski i Rumunii. Piłsudski nie widział wprawdzie bliskiego zagrożenia, niemniej w jego przekonaniu należało brać pod uwagę wszelkie ewentualności, w sytuacji gdy rządy w Związku Sowieckim sprawowali „neuropaci, morfiniści i kokainiści”29.

Przerwanie w początkach 1928 roku negocjacji z ZSRR w sprawie paktu o nieagresji, niepokój przed wzrostem agresywności z jego strony wobec Europy Środkowo-Wschodniej, a także utrzymywanie się linii współpracy sowiecko-niemieckiej nadały nowy impuls polityce Piłsudskiego wobec Rumunii. W rozmowie

${ }^{26}$ Tamże, s. 254; J. Piątek, Przesłanki decyzji rządu Stanleya Baldwina o zerwaniu stosunków dyplomatycznych ze Zwiazkiem Sowieckim 24 maja 1927 r. „Acta Universitatis Lodzienzis. Folia Historica" 2010, t. 85, s. 214; K. Neilson, Britain, Soviet Russia and the Collapse of the Versailles Order 1919-1939, Cambridge 2006, s. 53.

${ }^{27}$ Konferencja doszła do skutku w listopadzie 1927 r., zapewne w dniach od 14 do 23. T. Paulian, Istoricul legăturilor militare româno-polone (1921-1939), AMAE 71/1920-1944, Polonia, vol. 65, k. 271.

${ }^{28}$ H. Walczak, Sojusz z Rumunia $w$ polskiej polityce zagranicznej po zamachu majowym..., s. 256.

${ }^{29}$ Raport Iacovakyego do premiera Brătianu z 25.06.1927 r. (nr 2784), w: România-Polonia..., s. $99-102$. 
z wiceministrem spraw zagranicznych Alfredem Wysockim Marszałek akcentował, że Polska i Rumunia są ogniwami łączącymi morza Bałtyckie i Czarne, mają więc „olbrzymie możliwości wymiany towarów i ustalenia szlaku handlowego idącego od Gałaczu do Gdańska [i] od Dunaju do Wisły”. Przymierze z Rumunią traktował Piłsudski jako „najskuteczniejszą rękojmię pokoju i zabezpieczenia granic" obu krajów, toteż dążył do jego wzmocnienia i rozwinięcia. Z awersją odnosił się do Małej Ententy, jako alternatywę traktując blok z udziałem Polski, Węgier, Rumunii i Grecji, pozostający w ścisłych relacjach z państwami bałtyckimi i Francją. Realizacja tej kombinacji była możliwa dzięki spacyfikowaniu antagonizmu między Bukaresztem a Budapesztem. Dążenie do rozwiązania tego problemu stało się głównym celem planowanego wyjazdu Marszałka do Rumunii oraz jego częstych spotkań z Sándorem Belitską, posłem węgierskim w Polsce, któremu „kładł (...) w uszy konieczność pogodzenia Węgier z Rumunią,"30.

W czerwcu 1928 roku miała miejsce w Warszawie kolejna polsko-rumuńska konferencja międzysztabowa. O wadze, jaką przykładali do niej Polacy, świadczył udział Piłsudskiego jako Generalnego Inspektora Sił Zbrojnych. Na spotkaniu 6 czerwca z delegacją rumuńską, której przewodził gen. Nicolae Samsonovici, Marszałek zaprezentował swoje exposé. Założenia poprzednich studiów operacyjnych uznał za błędne, przewidywały one bowiem akcję bojową skoncentrowanymi już wojskami, bez uwzględnienia pierwszej fazy działań wojennych, których przebieg musiał przecież rzutować na dalszy ich tok. Żeby realnie prognozować bieg wypadków wojennych, należało w przekonaniu Piłsudskiego podjąć prace studyjne odnośnie do swoich i nieprzyjacielskich wojsk od pierwszego dnia mobilizacji, a następnie roztrząsać je dzień po dniu i godzina po godzinie. Ważną misję - jego zdaniem - miały do wypełnienia wojska osłonowe. Do ich zadań należał rekonesans w celu określenia słabych stron wojsk nieprzyjaciela, aby stworzyć możliwości przeciwnatarcia siłom głównym. Tylko w ten sposób można byłoby wypracowywać „dalsze logiczne decyzje”. Piłsudski sugerował Rumunom podobny model studiów operacyjnych w odniesieniu do ich wojsk, znajdujących się w strefie stykowej z armią polską oraz oddziałów stacjonujących w Besarabii. Marszałek gotów był osobiście uczestniczyć w pracach studyjnych, jeśli zostałyby one poprowadzone według jego zaleceń. Dezyderaty Piłsudskiego

${ }^{30}$ A. Wysocki, Dzieje mojej służby, Biblioteka Zakładu Narodowego im. Ossolińskich we Wrocławiu, sygn. 12477/II, t. 2, cz. 3, k. 30-31. 
zostały przesłane w formie noty do rumuńskiego ministra wojny, gen. Paula Angelescu, zyskując, z pewnymi zastrzeżeniami, jego aprobatę ${ }^{31}$.

Wyjazd Piłsudskiego do Rumunii służył pogłębieniu aliansu z Bukaresztem. Marszałek przebywał tam od 20 sierpnia do 2 października 1928 roku, oficjalnie w celach wypoczynkowych ${ }^{32}$, faktycznie zajmował się również sprawami politycznymi. 23 sierpnia Piłsudski gościł w letniej rezydencji królowej wdowy Marii w zamku Peleş w Sinai. Oprócz królowej rozmawiał tam również z patriarchą Mironem Cristeą, jednym z członków Regencji (pozostali to prezes Sądu Kasacyjnego Gheorghe Buzdugan i ks. Mikołaj). Prawdopodobnie przedmiotem wymiany zdań było położenie polityczne Rumunii, stosunki panujące w rodzinie królewskiej oraz perspektywy funkcjonowania aliansu polsko-rumuńskiego. W końcu sierpnia i na początku września Marszałek zwiedzał porty w Konstancy, Gałaczu i Braile. Można sądzić, że zaznajamiając się z tymi miastami, chciał się zorientować w możliwościach wykorzystania połączenia tranzytowego przez Rumunię do państw Europy Południowo-Wschodniej i Orientu dla eksportu polskich towarów. We wrześniu Piłsudski często peregrynował po Siedmiogrodzie (Cluj, Alba-Iulia, Oradea Mare, Sibiu i Braşov), przyglądając się miejscowym stosunkom i badając stopień unifikacji tego terytorium z Królestwem Rumunii. W ciągu ostatnich trzech dni, od 30 września do 2 października 1928 roku, Marszałek przebywał w Bukareszcie w charakterze oficjalnego gościa, spotykając się m.in. z premierem Vintilą Brătianu, ministrem spraw zagranicznych Constantinem Argetoianu oraz ministrem wojny, gen. Angelescu. Marszałek indagował gospodarzy o zaawansowanie przygotowań wojskowych ich kraju na wypadek wojny z ZSRR. Konstatował usatysfakcjonowanie Rumunów panującą sytuacją oraz ich ufność $\mathrm{w}$ gwarancje bezpieczeństwa wynikające $\mathrm{z}$ traktatów pokojowych podpisanych po I wojnie światowej. Piłsudski uważał, że miejscowi politycy lekceważą zagrożenie ze strony Związku Sowieckiego, a przeceniają ryzyko konfliktu z Węgrami. Polski gość bezskutecznie próbował wyczulić Rumunów

\footnotetext{
${ }^{31}$ Protokół z posiedzenia w Belwederze z 6.06.1928 r., „Przegląd Kawalerii i Broni Pancernej" 1988, nr 128, s. 251-252; Protokół konferencji odbytej 7.06.1928 r. między przedstawicielami armii polskiej i rumuńskiej, tamże, s. 253-255; Nota Piłsudskiego przekazana 9.06.1928 r. gen. Mărdărescu z adnotacjami gen. Angelescu, AMAE, 71/1920-1944, Polonia, vol. 65, k. 139-140.

${ }^{32}$ Piłsudski wybrał się tam w celu leczenia ,przewlekłego bronchitu i stałego zaflegmienia płuc" - A. Wysocki, Dzieje..., k. 31.
} 
na niebezpieczeństwo ze strony ZSRR oraz wpłynąć na zmniejszenie uprzedzeń wobec Madziarów ${ }^{33}$, tak więc efekty wizyty nie były szczególnie owocne.

Mimo braku widocznych rezultatów swojego pobytu w Rumunii Piłsudski postanowił kontynuować obrany kurs w kierunku pogłębienia przymierza. 27 grudnia 1928 roku, podczas spotkania z wiceministrem Wysockim i posłem RP w Bukareszcie Janem Szembekiem, przedstawił swoje plany. Stwierdził, że przejęcie przez niego władzy w Polsce dało jej możliwość realizowania samodzielnej polityki zagranicznej bez oglądania się na Paryż i Londyn, w odniesieniu do których chciał się trzymać tylko „ogólnych linii przymierzy” (chodziło tu, jak można sądzić, o alians z Francją). Wychodząc z założenia, że po zatargu z Litwą nastąpiło uspokojenie sytuacji w Europie Północnej, a w stosunku do pozostałych krajów bałtyckich możliwości prowadzenia ,polityki bardziej aktywnej” się wyczerpały, Piłsudski dostrzegł w Rumunii „pole naszego działania”. W jego opinii państwo to należało silniej związać z Polską, by podnieść efektywność aliansu jako zabezpieczenia przed agresją sowiecką. Marszałek zdawał sobie sprawę, że skutkiem tych działań może być rozbicie bloku dunajskiego. Nie przykładał jednak do tego wagi, ponieważ Czechosłowacja - wiodące państwo Małej Ententy - była „tworem sztucznym”, bezwartościowym z punktu widzenia jego programu działania. Zdaniem Piłsudskiego należało dążyć do zmiany naiwnego przekonania części sfer miarodajnych w Bukareszcie, że „pisane umowy czy zobowiązania” są „wystarczającą rękojmią pokoju i całości granic”. Istniała też, jak już wspomniano, konieczność oddziaływania na Rumunów w kierunku pozbycia się uprzedzeń wobec Węgier i porzucenia obojętnego nastawienia względem zagrożenia ze strony Moskwy. W opinii Marszałka należało też wspierać interesy Bukaresztu w Europejskiej Komisji Dunaju oraz umacniać jego zabiegi unifikujące Siedmiogród i Besarabię z resztą Królestwa. Pozytywną rolę w integracji Besarabii mogli odegrać Polacy zamieszkujący tę prowincję. Przed dyplomacją RP stanęło zadanie dbania o rozwój szkolnictwa i duszpasterstwa wśród tamtejszej ludności polskiej. Jeszcze w czasie swojego pobytu w Rumunii uzyskał Marszałek od premiera Brătianu i ministra oświaty Constantina Angelescu stosowne obietnice dotyczące przyjaznego odnoszenia się miejscowych władz do tych kwestii ${ }^{34}$.

${ }^{33}$ H. Walczak, Sojusz z Rumunia w polskiej polityce zagraniczej w latach 1918-1931..., s. 344-346.

${ }^{34}$ A. Wysocki, Dzieje..., k. 45-48. 
Okazją dla pożądanego przez Piłsudskiego głębszego sprzęgnięcia Rumunii z Polską stała się sowiecka propozycja podpisania protokołu o wcześniejszym wprowadzeniu w życie paktu paryskiego (Brianda-Kellogga) z 27 sierpnia 1928 roku. Marszałek gotów był wyrazić zgodę na sfinalizowanie tej oferty pod warunkiem objęcia nią Rumunii oraz państw bałtyckich. Zabiegi Polski okazały się skuteczne i Rumunia znalazła się wśród sygnatariuszy protokołu moskiewskiego mimo braku stosunków dyplomatycznych ze Związkiem Sowieckim i nieuregulowanej sprawy przynależności Besarabii ${ }^{35}$.

Kolejną sposobnością do zacieśnienia relacji polsko-rumuńskich była wizyta w Warszawie w lutym 1929 roku rumuńskiego ministra spraw zagranicznych Gheorghe Mironescu. Wiele wskazuje, że Marszałek w rozmowach z rumuńskim gościem podjął ponownie sprawę budowy pod auspicjami Polski bloku środkowoeuropejskiego z udziałem Rumunii, Węgier i państw bałtyckich, chroniącego swoich członków przed zagrożeniem sowieckim ${ }^{36}$. Piłsudski akcentował jednak bardzo mocno potrzebę uregulowania przez Rumunię stosunków z ZSRR. Starał się też rozwiać niepokoje Bukaresztu związane z utrzymywaniem dobrych stosunków z Budapesztem, podkreślając brak poparcia Warszawy dla tendencji rewizjonistycznych w polityce Węgier ${ }^{37}$. Jednocześnie Piłsudskiemu zależało na poprawie stosunków między Rumunią a Węgrami. Jak można sądzić, pewne nadzieje wiązał on $\mathrm{z}$ negocjacjami obu państw toczonymi w Wiedniu w sprawie optantów. Brak skłonności dyplomacji rumuńskiej do ustępstw sprawił, że po kilku dniach rozmowy te zostały zawieszone ${ }^{38}$.

Dystans Rumunów odnośnie do współpracy politycznej oraz zły stan ich armii pozbawiły Piłsudskiego - jak można sądzić - złudzeń co do możliwości pogłębienia aliansu i stworzenia opartego na nim bloku środkowoeuropejskiego.

${ }^{35} \mathrm{H}$. Bułhak, Pośrednictwo dyplomacji polskiej między Rumuniq a ZSRR w sprawie podpisania tzw. Protokołu Moskiewskiego (1928-1929), „Studia z Dziejów ZSRR i Europy Środkowej” (dalej: SZEŚ) 1983, t. 19, s. 92 i n.; A. Wysocki, Dzieje..., k. 71.

${ }^{36}$ Wspominał o tym na łamach dziennika „Adevěrul” towarzyszący Mironescu w Warszawie Liviu Nasta, określając tę kombinację mianem „bloku łacińskiego” - Biuletyn prasowy nr 8 z 9.03.1929 r., AAN, Ambasada w Bukareszcie, t. 341, k. 346.

${ }^{37} \mathrm{H}$. Walczak, Wizyta rumuńskiego ministra spraw zagranicznych Gheorghe Mironescu w Warszawie 24-27 lutego 1929 roku, w: Tantum possumus, quantum scimus. Ksiega pamiatkowa dedykowana profesorowi Zdzistawowi Chmielewskiemu w siedemdziesiata rocznice urodzin, red. R. Gaziński, A. Makowski, Szczecin 2012, s. 303-304.

${ }^{38}$ Raport szyfrowy Matuszewskiego do poselstwa w Bukareszcie z 22.03.1929 r. (nr 3), HIA, Rum., Ks.szyf. nr 3, p. 1, f. 3; Telegram Zaleskiego do poselstwa w Bukareszcie z 15.04.1929 r. (nr 49), tamże; Telegram Szembeka do MSZ z 19.04.1929 r. (nr 60), tamże. 
Skłoniło to Marszałka do stwierdzenia, wyrażonego 18 kwietnia 1929 roku wobec premiera Kazimierza Świtalskiego, że „nie wierzy najzupełniej”, by Rumunia była w stanie udzielić Polsce ,jakiejkolwiek istotnej pomocy” w razie pojawienia się groźnych zawirowań międzynarodowych i raczej stanie się „ofiarą Rosji”, aniżeli zaangażuje się przeciw niej, przychodząc w sukurs RP. Piłsudski był jednak zdania, ,ażeby w Rumunii odczuty był prestiż państwowy Polski, bo to może się nam w polityce zagranicznej przydać" ${ }^{\prime 39}$.

Pesymistyczne opinie Piłsudskiego dotyczące możliwości udzielenia pomocy Polsce $\mathrm{w}$ ewentualnej wojnie z ZSRR podzielali także inni polscy politycy i wojskowi. W Warszawie panowało przekonanie, że rola Rumunów w konflikcie ze Związkiem Sowieckim może się sprowadzić do obrony swego terytorium i biernego wiązania sił sowieckich. Alians z Rumunią nie miał jednak wariantu zastępczego i Polska niejako była nań skazana, przede wszystkim ze względu na potencjalne możliwości absorbowania uwagi Armii Czerwonej nad Dniestrem przez oddziały rumuńskie ${ }^{40}$.

Wyrazem funkcjonowania sojuszu była kolejna polsko-rumuńska konferencja międzysztabowa, która doszła do skutku w Warszawie na przełomie kwietnia i maja 1930 roku. Drugiego maja Piłsudski spotkał się w Belwederze z przewodniczącym delegacji rumuńskiej, gen. Nicolae Samsonovici. Dyskusja dotyczyła strefy stykowej obu armii i działań w pierwszym okresie wojny. Marszałek wskazywał na doniosłość skutecznej komunikacji między sojuszniczymi wojskami. Generał rumuński podzielał opinię Piłsudskiego. Zgodził się też z dezyderatem Marszałka co do konieczności ustanowienia kontaktów między polskim i rumuńskim inspektorem armii dla wyrobienia nawyku koniecznej w razie wojny kooperacji oraz dla wspólnych prac nad zagadnieniami operacyjnymi. Nie znalazła natomiast akceptacji gospodarza Belwederu rumuńska propozycja wspólnego dowodzenia w czasie konfliktu zbrojnego, ponieważ byłoby to pole do niepotrzebnych zadrażnień i spięć. W jego opinii kooperacja między obu wojskami będzie się realizowała w toku wojny niejako samoczynnie. Poproszony o przedstawienie swojej oceny w sprawie zachowania się Węgier i Niemiec w razie wojny Polski i Rumunii z ZSRR, Piłsudski

${ }^{39}$ K. Świtalski, Diariusz 1919-1935, do druku przygot. A. Garlicki i R. Świętek, Warszawa 1992, s. 389 (stąd cytaty); Raport mjr. Michałowskiego do szefa Oddziału II z 15.04.1929 r. (nr 80), AAN, Sztab Główny, 616, t. 128, k. 38-46.

${ }^{40}$ Raport mjr. Michałowskiego do Szefa Oddziału II z 3.09.1930 r. (nr 199), AAN, Ataszaty Wojskowe RP AII 25, k. 1056; opracowanie mjr. Michałowskiego, Charakterystyka Rumunii jako sprzymierzeńca wojskowego na wypadek zatargu z Rosją Sowiecką, 18 X 1930 r., tamże, k. 80. 
stwierdził, że Warszawa i Bukareszt będą mogły liczyć na pomoc moralną Europy i Stanów Zjednoczonych, i że to powstrzyma Berlin i Budapeszt przed opowiedzeniem się po stronie Moskwy. Działania wojenne będą zatem prowadzone jedynie na froncie wschodnim. Podsumowując rezultaty prac konferencji, Marszałek stwierdził, że czynią one „styk polsko-rumuński bardziej solidnym”»11. Wydaje się jednak, że były to okolicznościowe słowa uznania. Stan armii rumuńskiej nie poprawił się radykalnie, zapewne zatem Piłsudski również nie przewartościował swoich wcześniejszych ocen. Warto też dodać, że gen. Samsonovici, oceniając pro domo sua wyniki konferencji, stwierdził, że Rumunia także nie będzie mogła liczyć w konflikcie z ZSRR na bezpośrednią pomoc RP i musi brać w rachubę jedynie własne siły dla przeciwstawienia się Armii Czerwonej ${ }^{42}$.

W październiku 1931 roku Piłsudski udał się na wypoczynek do Rumunii. W trakcie pobytu prowadził rozmowy polityczne z królem Karolem II, premierem Nicolae Iorgą oraz ministrem spraw zagranicznych Dimitrie Ghiką. Monarcha rumuński mianował wówczas Marszałka szefem 16. pułku piechoty w Fălticeni. Jak się wydaje, głównym tematem dyskusji była kwestia zawarcia przez Polskę i Rumunię oraz państwa bałtyckie układu o nieagresji ze Związkiem Sowieckim. Sprawa ta miała związek ze wzrostem w Niemczech na początku lat trzydziestych godzących we Francję tendencji rewizjonistycznych. Paryż podjął wówczas poszukiwanie alternatywy dla prowadzonej po Locarno polityki porozumienia z Niemcami. Taką alternatywą jawił się Związek Sowiecki, dostrzegający w polityce Berlina skłonności do odejścia od dotychczasowej linii współpracy symbolizowanej przez układ w Rapallo. W Polsce, narażonej na rewanżyzm ze strony Rzeszy, owe zmiany odbierano jako korzystne, gdyż podważały one szkodliwe dla niej współdziałanie niemiecko-francuskie i niemiecko-sowieckie. Dlatego też w Warszawie z zainteresowaniem potraktowano inicjatywę Francji zawarcia ze Związkiem Sowieckim paktu o nieagresji, powracając do projektu układu o nieagresji z ZSRR z 1925 roku z udziałem Polski, Rumunii i państw bałtyckich. Rumuni jednak żywili obawy, że negocjacje w sprawie paktu mogłyby otworzyć kwestionowanie przez Moskwę przynależności Besarabii, a po jego sfinalizowaniu ułatwić szerzenie się wpływów komunistycznych w Rumunii.

\footnotetext{
${ }^{41}$ Notatki z rozmowy p. marsz. Piłsudskiego z p. szefem szt.[abu] gł.[ównego] rumuń.[skiego] gen. dyw. Samsonovici spisane przez szefa szt.[abu] gł.[ównego], gen. dyw. Piskora w Belwederze 2 maja 1930. Archiwum Instytutu Polskiego i Muzeum im. gen. Sikorskiego w Londynie, Oddział III SG, AII 26A/1 (stąd cytat); Gen. Samsonovici, Chestiunile operative discutate la Varşovia. No 621 din 6.05.1930, AMR. MSM. Secţia 3. Operaţi. T. 1315, k. 120, 123-125

${ }^{42}$ Gen. Samsonovici, Chestiunile operative..., k. 291.
} 
W czasie swojej wizyty Piłsudski starał się uspokoić Rumunów co do respektowania ich interesów. Poinformował także o przyrzeczeniu Francji niepodpisywania paktu z Rosjanami bez skorelowania tej sprawy z Polską. Z kolei Warszawa miała zharmonizować finalizację swojego paktu z ZSRR z zawarciem przez Rumunię jej układu ze Związkiem Sowieckim. W rozmowach z gospodarzami Marszałek poruszał także kwestię niestawiania przeszkód rozwojowi polskiego szkolnictwa w Rumunii oraz zabiegał o wypłacenie odszkodowań polskim właścicielom ziemskim na Bukowinie, wywłaszczonym przez rząd królewski po I wojnie światowej ${ }^{43}$.

Urlop Piłsudskiego w Rumunii miał dość nieoczekiwany przebieg. Przebywając w miejscowości Techirghiol niedaleko Konstancy, Marszałek nabawił się zapalenia płuc, co wyglądało bardzo groźnie. Z wysoką gorączką przewieziono go do Bukaresztu, gdzie zamieszkał w polskim poselstwie. Stan chorego wykluczał natychmiastowy powrót do kraju. Dopiero po kilku dniach, 28 października, mógł udać się do Polski ${ }^{4}$.

Sprawa zawarcia układu o nieagresji przez Rumunię i ZSRR znalazła się w zastoju po niepowodzeniu rozmów prowadzonych przez obie strony i zmianie rządu we Francji, skutkującej zmniejszeniem zainteresowania Paryża finalizacją własnego układu z ZSRR oraz paktów państw Europy Środkowo-Wschodniej. W zabiegi na rzecz przezwyciężenia impasu włączył się Piłsudski. W drodze powrotnej z wypoczynku w Egipcie zatrzymał się on w Bukareszcie, gdzie 14 kwietnia 1932 roku konferował z premierem Iorgą i ministrem spraw zagranicznych Ghiką. Marszałek ostro wypowiadał się o Francji, której politycy „z wzajemnej nienawiści zmieniają linię polityczną z dnia na dzień”. Tak - zdaniem Piłsudskiego - potraktowano pakt o nieagresji, który następca Aristide’a Brianda, André Tardieu ${ }^{45}$, umieścił „w koszu na śmieci”, mimo że Francja sama była jego inicjatorką i naciskała w tym kierunku na Polskę. Marszałek zawiadomił Rumunów o podpisaniu układów o nieagresji przez Finlandię i Łotwę oraz zapowiedział, że po zawarciu układu sowiecko-estońskiego ${ }^{46}$ i w wypadku dalszego oporu

${ }^{43}$ W. Jędrzejewicz, J. Cisek, Kalendarium życia Józefa Piłsudskiego 1867-1935, t. 3: 1926-1935, Wrocław 1994, s. 224; H. Walczak, Polska a sprawa rumuńsko-sowieckiego paktu o nieagresji w latach 1931-1932 (cz. 1), „Studia z Dziejów Rosji i Europy Środkowo-Wschodniej” (dalej: SDREŚW) 2014, t. 49, z. 2, s. 76-84; C. Argetoianu, Memorii. Pentru cei de mâine. Amintiri din vremea celor de ieri, vol. 9, part. 8 (1930-1931), ediție și indice S. Neagoe, Bururești 1997, s. 419.

${ }^{44}$ W. Jędrzejewicz, J. Cisek, Kalendarium życia ..., s. 224-225.

45 Tardieu był ministrem spraw zagranicznych od 23 lutego do 3 czerwca $1932 \mathrm{r}$.

${ }^{46}$ W 1932 r. Związek Sowiecki podpisał pakty o nieagresji: z Finlandią - 21 stycznia, Łotwą 5 lutego i z Estonią - 5 maja. 
Rumunii wobec paktu z ZSRR Polska podpisze swój pakt z Moskwą. Aby złagodzić u Rumunów rezonans swoich słów oraz ich poczucie osamotnienia dodał, że Polska dopuszcza ewentualność równoczesnej ratyfikacji układów polsko-sowieckiego i rumuńsko-sowieckiego. Słowa Piłsudskiego zrobiły duże wrażenie na Ghice, który zadeklarował chęć rozmów z Moskwą, domagał się jednak wystąpienia Francji i Polski jako mediatorów i wynegocjowania warunków wstępnych, z których głównym było usunięcie z tekstu paktu jakichkolwiek wzmianek o Besarabii ${ }^{47}$.

W ciągu kolejnych tygodni, mimo podejmowanych przez dyplomację polską prób pośrednictwa, nie udało się posunąć do przodu sprawy paktu rumuńsko-sowieckiego. Polska zatem zdecydowała się na zawarcie swojego układu w możliwie najbliższej przyszłości. Na początku lipca 1932 roku odwiedził Piłsudskiego w Warszawie Victor Cădere, rumuński poseł. Zadeklarował on gotowość podpisania przez Rumunię układu z ZSRR, prosząc o prolongatę zawarcia przez RP jej paktu z Moskwą do momentu zakończenia negocjacji sowiecko-rumuńskich. Cădere argumentował, że odrzucenie tej prośby poszerzyłoby pole manewru dyplomacji sowieckiej w rokowaniach z Rumunami oraz nadwyrężyłoby przymierze polsko-rumuńskie. Marszałek dobrze przyjął oświadczenie rumuńskiego posła. Uznał jednak przełożenie zawarcia paktu polsko-sowieckiego za niemożliwe, gdyż państwa bałtyckie sfinalizowały już swoje układy z ZSRR, a Warszawa już wcześniej, właśnie na skutek próśb Rumunii, straciła szansę podpisania swojego paktu jednocześnie z Bałtami. Piłsudski uważał, że Moskwa z powodu trudności wewnętrznych, osłabienia współpracy z Rzeszą oraz obaw przed konflitem z Japonią zechce podpisać pakt z Rumunią. Tę koniunkturę, zdaniem Marszałka, Bukareszt powinien wykorzystać, Polska natomiast w miarę możliwości miała nie śpieszyć się z podpisaniem swojego paktu. Jeśli dyplomacja rumuńska nie wykorzystałaby tej ewentualności i pakt polsko-sowiecki stałby się faktem, Warszawa była jeszcze skłonna opóźniać ratyfikację własnego układu. Rumuni nie zdołali jednak wynegocjować swojego paktu przed podpisaniem układu polsko-sowieckiego. Nie na wiele zdało się też spowalnianie przez Polskę ratyfikacji ze względu na opór Rumunii przed wprowadzeniem do treści jej układu z Moskwą jakiejkolwiek sugestii o problemie besarabskim. Cieniem na tych negocjacjach położyło się negatywne stanowisko wobec paktu Nicolae Titulescu - dyplomaty

\footnotetext{
${ }^{47}$ Notatka ze spotkania Iorgi i Ghiki z Piłsudskim i Szembekiem z 14.04 .1932 r., w: Behind closed doors. Secret papers on the failure of Romanian-Soviet negotiations 1931-1932, translated, with an introductory essay by W.M. Bacon, Stanford 1979, s. 97-99.
} 
mającego bardzo duży wpływ na rumuńską politykę zagraniczną, który żywiąc podobne obawy przed zawarciem układu, jak inni politycy bukareszteńscy, najpierw ze względów ambicjonalnych zwalczał jakikolwiek kompromis, a zostawszy szefem dyplomacji królewskiej, doprowadził do przekreślenia osiągniętego już modus vivendi ${ }^{48}$.

Wraz z objęciem w październiku 1932 roku resortu spraw zagranicznych przez Titulescu alians Polski i Rumunii stanął na rozdrożu. Nowy minister wychodził bowiem z założenia, że podstawą bezpieczeństwa Rumunii nie mogą być alianse z państwami równorzędnymi, ponieważ nie są one w stanie zneutralizować niebezpieczeństwa napaści ze strony wielkiego mocarstwa. Stąd też zamierzał doprowadzić do takiego uformowania relacji z wielkimi mocarstwami, aby agresywne zamiary wobec Rumunii jednego $\mathrm{z}$ nich stawiały go $\mathrm{w}$ obliczu zbrojnej reakcji pozostałych mocarstw. W tej sytuacji przymierze $\mathrm{z}$ niebędąca mocarstwem Polską musiało tracić na wartości w oczach Titulescu. Pierwsze większe dysonanse między obu sprzymierzeńcami pojawiły się w stosunku do Paktu Czterech, z którego projektem wystąpił Benito Mussolini w marcu 1933 roku. Piłsudski był przeciwnikiem porozumienia czterech potęg narzucających swoją wolę państwom mniejszym. Titulescu początkowo podzielał ten pogląd. Potem jednak, ulegając perswazji Francji, zmienił swoje nastawienie, akceptując pakt w wersji zmodyfikowanej przez Paryż. Polska natomiast pozostała nieugięta w swojej postawie ${ }^{49}$.

Realizując linię polityczną oparcia bezpieczeństwa Rumunii na wielkich mocarstwach, Titulescu podjął zabiegi na rzecz uregulowania stosunków ze Związkiem Sowieckim. Okazją dla nawiązania rozmów stały się negocjacje dotyczące zawarcia konwencji o definicji agresora. Ich sfinalizowanie nastąpiło w lipcu 1933 roku w Londynie, natomiast wymiana dokumentów ratyfikacyjnych między Rumunią a ZSRR nastąpiła w Warszawie w październiku 1933 roku przy okazji wizyty Titulescu, przebiegającej w dobrej atmosferze. Rumuński polityk został przyjęty przez Piłsudskiego na audiencji w Belwederze. Marszałek zrobił na nim „niezwykle silne wrażenie i zostawił uczucie głębokiego szacunku”.

${ }^{48}$ H. Walczak, Polska a sprawa rumuńsko-sowieckiego paktu o nieagresji w latach 1931-1932 (cz. 2), SDREŚW 2015, t. 50, z. 1, s. 45-81.

49 Telegram Cădere do MSZ z 7.04.1933 r. (nr 1675), AMAE, 71/1920-1944, Polonia, vol. 2, k. 165-168; Raport Cădere do Titulescu z 7.06.1933 r. (nr 2576), AMAE, Mica Înțelegere, vol. 31, k. 321-324; H. Bułhak, Polska a Rumunia..., s. 332; A. Zieliński, Stosunki polsko-rumuńskie, grudzień 1933 - maj 1935, SZEŚ, 1976, t. 12, s. 158-159; J. Beck, Wspomnienia o polskiej polityce zagranicznej 1926-1939, Warszawa-Kraków 2015, s. 86-87. 
Titulescu uznał, iż jest on „postacią, która nie ma sobie równej" ${ }^{50}$. Wydaje się, że Rumun nie wywołał w Piłsudskim porównywalnych emocji. Zapewne też musiało Marszałka zaniepokoić zdanie z oświadczenia Titulescu, że „Rumunia pragnie uczynić wszystko, co jest w jej mocy, aby stosunki jej z Sowietami stały się naprawdę serdeczne" ${ }^{\circ 1}$.

Podpisana z Niemcami w styczniu 1934 roku deklaracja o niestosowaniu przemocy, będąca - wraz z paktem o nieagresji z ZSRR - podstawą polityki Piłsudskiego, czyli utrzymywaniem przez Polskę równych odległości między dwoma wielkimi sąsiadami i niepodejmowaniem współpracy z żadnym z nich przeciwko drugiemu, została przyjęta w Bukareszcie dość chłodno. Żywiono tam obawy, że odprężenie na granicy polsko-niemieckiej wzmoże obecność Rzeszy w Europie dunajskiej, gdzie rozwój sytuacji żywotnie interesował Rumunów. Aby uspokoić sojuszników, Piłsudski w obecności Becka złożył posłowi Cădere ${ }^{52}$ stosowne wyjaśnienia. Stwierdził, że podpisanie deklaracji jest wyrazem niezależności polskiej polityki zagranicznej. Podkreślił też, że dokument ten nie wprowadza żadnych, nawet najmniejszych zmian w stosunkach RP z jej sprzymierzeńcami, których istotą jest bezwzględne przestrzeganie zobowiązań. Marszałek kategorycznie zaprzeczył, jakoby zostały podjęte jakiekolwiek tajne ustalenia lub też były dyskutowane inne kwestie niż zamieszczone w deklaracji. Zaznaczył też, że układ z 26 stycznia został zawarty w obliczu ustępstw Paryża wobec Rzeszy i braku stanowczości Francji w zapewnieniu respektowania powojennych traktatów, których sama jest gwarantką 53 .

\footnotetext{
${ }^{50}$ Min.[ister] Titulescu o wynikach swych konferencyj w Warszawie, „Ilustrowany Kurier Codzienny", 12.10 .1933 r., s. 16 (stąd cytat); Raport prasowy Kobylańskiego do MSZ z 11.10.1933 r. (nr 323/R/50), AAN, Sztab Główny 616, t. 324, k. 439-441; Raport V. Cădere [winno być N. Mishu] do podsekretarza stanu w MSZ S. Rădulescu z 15.10.1933 r., w: România-Polonia ..., s. 156158; Raport N. Mishu do Titulescu z 7.11.1933 r. (nr 4470), AMAE, Polonia, vol. 2, k. 224-225; A. Skrzypek, Zagadnienia rumuńskie $w$ stosunkach polsko-radzieckich w latach 1932-1938, w: Z dziejów stosunków polsko-radzieckich. Studia i materiaty, t. 11-12, Warszawa 1975, s. 197; S. Żerko, Kryzys w stosunkach między Polska a Rumunia w latach 1934-1936 w świetle polskich dokumentów dyplomatycznych, „Dzieje Najnowsze” 2016, t. 48, nr 2, s. 9.

${ }^{51}$ Oświadczenie ministra Titulescu, „Gazeta Polska” z 11.10.1933 r., s. 1.

52 Tego samego dnia, tyle że wcześniej, uczynił to Piłsudski wobec ambasadora Francji w Polsce, Julesa Laroche'a - J. Laroche, Polska lat 1926-1935, Warszawa 1966, s. 149.

${ }^{53}$ Telegram Cădere do MSZ z 29.01.1934 r. (nr 421), AMAE, Polonia, vol. 3, k. 16-18; Raport Cădere do Titulescu z 1.02.1934 r. (467); tamże, Dosare specjale, vol. 241/3, k. 123-128; J. Laroche, Polska..., s. 147-149; A. Zieliński, Stosunki polsko-rumuńskie..., s. 167-169.
} 
Wiosną 1934 roku linie polityki Polski i Rumunii zaczęły się wyraźnie rozchodzić, co uwidoczniło się zwłaszcza na tle krystalizującej się, firmowanej przez Francję i ZSRR koncepcji paktu wschodniego. Projekt ten, zakładający uczestnictwo Moskwy w multilateralnym układzie gwarantującym wzajemną pomoc swoich członków na wypadek agresji przeciwko jednemu z nich, Piłsudski uważał za szkodliwy dla Polski. W efekcie bowiem rosła rola Związku Sowieckiego w Europie Środkowo-Wschodniej z oczywistym zdegradowaniem pozycji Polski oraz jej aliansów z Francją i Rumunią. Marszałek przy różnych okazjach podkreślał, że polityka zagraniczna RP opiera się przede wszystkim na przymierzach z Paryżem i Bukaresztem, a Polska zachowuje wolną w rękę regulowaniu relacji z Moskwą i Berlinem. Piłsudski zdawał sobie sprawę ze słabości Rumunii i przymierze z nią traktował jako czynnik rozszerzający pole manewru politycznego, przewidując militarne osamotnienie Polski w razie wojny ze Związkiem Sowieckim. Z pewnością nie nastrajała go optymistycznie ewolucja polityki rumuńskiej i zabiegi Titulescu na rzecz zbliżenia z Moskwą, podjęte z pominięciem Warszawy. Wyrazem tego kursu była propozycja wysunięta wobec ZSRR zawarcia paktu trójstronnego polsko-rumuńsko-sowieckiego, zakładającego udzielenie pomocy ofierze agresji i akcji przeciwko napastnikowi ze strony trzeciego państwa. Szef rumuńskiej dyplomacji przewidywał, że w razie odmowy Warszawy przystąpienia do tego układu przymierze z nią nie byłoby prolongowane ${ }^{54}$. U schyłku życia Marszałka perspektywy aliansu z Rumunią rysowały się zatem nader niepewnie.

Józef Piłsudski od początku niepodległego bytu Rzeczypospolitej stał się orędownikiem jej bliskiej współpracy z Rumunią. Nastawienie to wynikało z bieżących przesłanek i związane było z kształtowaniem się wschodnich granic państwa polskiego. Istotną rolę w tej współpracy odgrywała kwestia ukraińska, najpierw współdziałanie przeciwko Zachodnioukraińskiej Republice Ludowej, a potem plany wspierania Ukrainy petlurowskiej, mającej być bastionem chroniącym oba państwa przed ekspansją Rosji. Ten właśnie aspekt zdecydował o zawarciu przymierza polsko-rumuńskiego w 1921 roku, które stało się fundamentem polskiej polityki zagranicznej. Marszałek był zwolennikiem jego pogłębiania i zacieśniania. Temu właśnie służyła jego podróż do Rumunii we wrześniu 1922

\footnotetext{
${ }^{54}$ Raport Cădere do Titulescu z 27.04.1934 (nr 1865), AMAE, Polonia, vol. 38, k. 146-147; Diariusz i teki Jana Szembeka (1935-1945), t. 1, oprac. T. Komarnicki, Londyn 1964, s. 155, 255-256, 267; J. Laroche, Polska..., s. 157-188; A. Zieliński, Stosunki polsko-rumuńskie..., s. 174-179; A. Skrzypek, Zagadnienia rumuńskie..., s. 198-199; S. Żerko, Kryzys..., s. 10-12.
} 
roku. Jednakże zmiany związane z dojściem do władzy centroprawicy spowodowały usunięcie się Piłsudskiego z życia politycznego i utratę możliwości oddziaływania na kształt aliansu z Rumunią. Sytuacja ta uległa zmianie po zamachu majowym i powrocie Marszałka do władzy. Piłsudski ponownie zaczął głosić konieczność bliskiej współpracy z Rumunią, mającej służyć budowie szerszej konstelacji państw Europy Środkowo-Wschodniej jako formy zabezpieczenia tego regionu przed zagrożeniem ze strony Związku Sowieckiego. Działania te były szczególnie intensywne w 1928 roku. Niedocenianie przez polityków rumuńskich niebezpieczeństwa ze strony ZSRR oraz opłakany stan armii królewskiej uzmysłowiły Piłsudskiemu nierealność tej koncepcji. Innej alternatywy dla aliansu polsko-rumuńskiego jako elementu poszerzającego pole manewru polskiej polityki zagranicznej wobec Moskwy jednak nie widział i był przekonany o konieczności jego utrzymania. $Z$ dużą determinacją zabiegał o koordynację działań limitrofów ZSRR w zakresie zawierania z tym państwem układów o nieagresji. Opór Bukaresztu próbował przezwyciężyć nawet drogą nacisku dyplomatycznego. Mimo fiaska tych wysiłków oraz zmian sytuacji międzynarodowej na początku lat trzydziestych nadal był przekonany o znaczeniu sojuszu z Rumunią dla działań międzynarodowych Polski.

\section{Bibliografia}

\section{Źródła archiwalne}

\section{Archiwum Akt Nowych w Warszawie}

Akta B. Wieniawy-Długoszowskiego.

Ataszaty Wojskowe RP.

Sztab Główny, 616.

Archiwum Instytutu Polskiego i Muzeum im. gen. Sikorskiego w Londynie

Oddział III SG. AII 26A.

\section{Arhivele Ministerului Afacerilor Externe, Bucureşti}

$71 / 1914$, E2, partea I.

71/1920-1944, Polonia.

Dosare specjale.

Mica Înţelegere. 


\section{Arhivele Militare Române, Bucureşti}

Marele Stat Major

Biroul Ataşati Militari,

Secţia 3. Operaţi.

\section{Hoover Institution Archives}

Polska. Poselstwo (Rumunia). Księga szyfrów.

\section{Biblioteka Zaktadu Narodowego im. Ossolińskich we Wrocławiu}

Wysocki A., Dzieje mojej stużby, sygn. 12477/II, t. 2, cz. 3.

\section{Źródła drukowane}

Argetoianu C., Memorii. Pentru cei de mâine. Amintiri din vremea celor de ieri, vol. 9, part. 8 (1930-1931), ediție și indice S. Neagoe, Bururești 1997.

Beck J., Wspomnienia o polskiej polityce zagranicznej 1926-1939, Warszawa-Kraków 2015.

Behind closed doors. Secret papers on the failure of Romanian-Soviet negotiations 19311932, translated, with an introductory essay, by W.M. Bacon, Stanford 1979.

Bułhak H., Materiały do dziejów sojuszu polsko-rumuńskiego w latach 1921-1931, „Studia Historyczne" 1973, z. 3.

Diariusz i teki Jana Szembeka (1935-1945), t. 1, oprac. T. Komarnicki, Londyn 1964.

Documents on British Foreign Policy 1919-1939, Series I, vol. XXIII.

Grzybowski W., Spotkania i rozmowy z Józefem Piłsudskim, „Niepodległość” (Londyn) 1948, t. 1.

Hunczak T., Ukraine and Poland in documents 1918-1922, part 2, New York-Toronto 1983.

Korwin-Sokołowski A.L., Fragmenty wspomnień 1910-1945, Warszawa 1987.

Laroche J., Polska lat 1926-1935, Warszawa 1966.

List J. Piłsudskiego do gen. K. Sosnkowskiego z 29 IV 1920 r., „Niepodległość” 1962, t. 7.

Piłsudski J., Pisma zbiorowe, t. 5, Warszawa 1937.

Piłsudski J., Pisma zbiorowe, t. 10, Warszawa 1938,

Protokół konferencji odbytej 7.06.1928 r. między przedstawicielami armii polskiej i rumuńskiej, „Przegląd Kawalerii i Broni Pancernej” 1988, nr 128.

Protokół z posiedzenia w Belwederze z 6.06.1928 r., „Przegląd Kawalerii i Broni Pancernej" 1988, nr 128.

România-Polonia. Relaţii diplomatice, col. de red. F. Anghel, N. Mareş, D. Preda, Bucureşti 2003. 
Sprawy polskie na konferencji pokojowej w Paryżu w 1919 r. Dokumenty i materiały, t. 2, red. R. Bierzanek, J. Kukułka, Warszawa 1967.

Świtalski K., Diariusz 1919-1935, do druku przygot. A. Garlicki, R. Świętek, Warszawa 1992.

Prasa

Gazeta Polska 1933

Ilustrowany Kurier Codzienny 1933

Kurier Warszawski 1920

Opracowania

Anghel F., Okupacja Pokucia przez Armię Rumuńska (24 maja-początek sierpnia 1919 r.) i początki stosunków polsko-rumuńskich, „Przegląd Historyczny” 1998, z. 2.

Bułhak H., Początki sojuszu polsko-rumuńskiego i przebieg rokowań o konwencję wojskowa w latach 1919-1921, „Dzieje Najnowsze” 1973, nr 3.

Bułhak H., Pośrednictwo dyplomacji polskiej między Rumunia a ZSRR w sprawie podpisania tzw. Protokotu Moskiewskiego (1928-1929), „Studia z Dziejów ZSRR i Europy Środkowej" 1983, t. 19.

Essen A., Polska a Mała Ententa: 1920-1934, Warszawa-Kraków 1992.

Hrenciuc D., România şi Polonia -1918-1931. Relaţii politice, diplomatice şi militare, Rădăuţi 2003

Jędrzejewicz W., Cisek J., Kalendarium życia Józefa Piłsudskiego 1867-1935, t. 2: 19181926, t. 3: 1926-1935, Wrocław-Kraków 1994.

Józef Piłsudski (1867-1935). Polityk, wódz, mąż stanu, red. J. Faryś, T. Sikorski, Szczecin 2005.

Kroytor V., Problema Pokuttiya u vidnostinakh mizh Rumunieyiu i ZUNR, „Galitschina” 2001, nr 5-6.

Leczyk M., Polska i sąsiedzi. Stosunki wojskowe 1921-1939, Białystok 1997.

Mareș N., Istorie - diplomație. Eseuri, vol. 2, Iași 2014.

Między Europa naszych pragnień a Europa naszych możliwości, red. J. Faryś, T. Sikorski, P. Słowiński, t. 2, Gorzów Wlkp. 2007.

Międzymorze. Nadzieje i ograniczenia w polityce II Rzeczypospolitej, red. E. Znamierowska-Rakk, Warszawa 2016.

Neilson K., Britain, Soviet Russia and the Collapse of the Versailles Order 1919-1939, Cambridge 2006.

Pajewski J., Budowa Drugiej Rzeczypospolitej 1918-1926, Kraków 1995.

Piątek J., Przesłanki decyzji rządu Stanleya Baldwina o zerwaniu stosunków dyplomatycznych ze Zwiazkiem Sowieckim 24 maja 1927 r., „Acta Universitatis Lodzienzis. Folia Historica" 2010, t. 85. 
Polska i Rumunia w Europie Środkowej w XX i XXI wieku. Studia, materiały i eseje poświęcone pamięci prof. dra hab. Wojciecha Rojka. Polonia şi România în Europa Centrală în secolele XX și XXI. Studii, materiale și eseuri dedicate in memoriam prof. dr univ. Wojciech Rojek, red. A. Kastory, H. Walczak, Kraków 2017.

Popescu M.C., Relaţiile militare româno-polone în perioada interbelică (1918-1939), Bucureşti 2001.

Post hominum memoriam. Profesorowi Januszowi Farysiowi-uczniowie i przyjaciele, red. E. Skorupska-Raczyńska, P. Słowiński, Gorzów Wlkp. 2009.

Przyjaźnie i antagonizmy. Stosunki Polski z państwami sąsiednimi w latach 1918-1939, red. J. Żarnowski. Warszawa 1977.

Stănescu M.C., Operaţia Pocuţia, mai-august 1919, „Magazin Istoric” 1995, nr 1.

Stępniak W., Dyplomacja polska na Bałkanach (1918-1926), Warszawa 1998.

Tantum possumus, quantum scimus. Księga pamiątkowa dedykowana profesorowi Zdzisławowi Chmielewskiemu $w$ siedemdziesiąta rocznice urodzin, red. R. Gaziński, A. Makowski, Szczecin 2012.

Walczak H., Polscy przedstawiciele dyplomatyczni w Rumunii w latach 1918-1940, cz. 1: 1918-1940, „Polish Biographical Studies” 2016, nr 4.

Walczak H., Polska a sprawa rumuńsko-sowieckiego paktu o nieagresji w latach 19311932 (cz. 1), „Studia z Dziejów Rosji i Europy Środkowo-Wschodniej” 2014, t. 49.

Walczak H., Polska a sprawa rumuńsko-sowieckiego paktu o nieagresji w latach 19311932, (cz. 2), „Studia z Dziejów Rosji i Europy Środkowo-Wschodniej” 2015, t. 50.

Walczak H., Sojusz z Rumunia w polskiej polityce zagranicznej w latach 1918-1931, Szczecin 2008.

Wandycz P., Z Pitsudskim i Sikorskim. August Zaleski - minister spraw zagranicznych w latach 1926-1932, 1939-1941, Warszawa 1999.

Willaume M., Rumunia, Warszawa 2004.

Z dziejów stosunków polsko-radzieckich. Studia i materiały, t. 11-12, Warszawa 1975.

Zieliński A., Stosunki polsko-rumuńskie, grudzień 1933 - maj 1935, „Studia z Dziejów ZSRR i Europy Środkowej” 1976, t. 12.

Żerko S., Kryzys w stosunkach między Polska a Rumuniq w latach 1934- 1936 w świetle polskich dokumentów dyplomatycznych, „Dzieje Najnowsze” 2016, t. 48.

\section{Abstrakt}

Józef Piłsudski od początku niepodległego bytu Rzeczypospolitej stał się orędownikiem jej bliskiej współpracy z Rumunią. Nastawienie to wiązało się z potrzebą zabezpieczenia wschodnich granic państwa polskiego. Ten właśnie aspekt zdecydował o zawarciu przymierza polsko-rumuńskiego w 1921 roku, asekurującego Warszawę i Bukareszt przed 
zagrożeniem ze strony Moskwy. Uważając ten alians za jednen z fundamentów polskiej polityki zagranicznej, Marszałek był zwolennikiem jego pogłębiania i zacieśniania. Temu właśnie służyła jego podróż do Rumunii we wrześniu 1922 roku. Zmiany związane z dojściem do władzy centroprawicy spowodowały jednakże usunięcie się Piłsudskiego z życia politycznego i utratę możliwości oddziaływania na kształt aliansu z Rumunią. Sytuacja ta uległa zmianie po zamachu majowym i powrocie Marszałka do władzy. Ponownie zaczął on głosić konieczność bliskiej współpracy z Rumunią, która miała służyć budowie szerszej konstelacji państw Europy Środkowo-Wschodniej jako formy zabezpieczenia tego regionu przed zagrożeniem ze strony Związku Sowieckiego. Z tego też powodu Piłsudski z dużą determinacją zabiegał o koordynację działań limitrofów ZSRR w zakresie zawierania z tym państwem układów o nieagresji. Mimo fiaska tych wysiłków oraz zmian sytuacji międzynarodowej na początku lat trzydziestych nadal był przekonany o istotnym znaczeniu sojuszu z Rumunią dla polskiej polityki zagranicznej.

\title{
Józef Pilsudski and the Polish-Romanian Alliance in the Interwar Period
}

\begin{abstract}
Józef Piłsudski had been an advocate of the close cooperation between Poland and Romania since the beginning of the independence. This attitude resulted from the current premises and was connected with the formation of the eastern borders of the Polish state. A substantial role in this cooperation was played by the Ukrainian issue, firstly cooperation against the West Ukrainian People's Republic (ZUNR) and then the plans to support Petlura's Ukraine, which was supposed to constitute a bastion protecting both countries from Russia's expansion. This very aspect determined the conclusion of the Polish-Romanian alliance in 1921, which became the foundation of Polish foreign policy. The Marshal was a proponent of its tightening and strengthening. His journey to Romania in September 1922 was devoted to this aim. However, the changes resulted from the accession to power of the centre-right led to the removal of Piłsudski from political life and the loss of the possibility of influencing the alliance with Romania. This situation changed after the May coup and the Marshal's return to power. He started propagating the need for the closer collaboration with Romania again. It was to serve the construction of a wider constellation of Central and Eastern European countries as a form of protecting this region against the threat posed by the Soviet Union. These activities were particularly intense in 1928. The underestimation of the danger by Romanian politicians and the deplorable state of the army made Piłsudski realize that this concept was illusory. However, he did not see another alternative to the Polish-Romanian alliance as an element allowing some leeway
\end{abstract}


in Polish foreign policy towards Moscow and he was convinced of the need to maintain it. With great determination, he sought to coordinate the activities of the USSR's limitrophes in concluding non-aggression pacts with that country. He even tried to overcome the resistance of Bucharest by diplomatic pressure. Despite the fiasco of these efforts and changes in the international situation in the early 1930's, he was still convinced of the importance of the alliance with Romania for Poland's international activities. 